\title{
Total Volume and Aboveground Biomass Models for Juniperus procera Plantation in Wondo Genet, Southern Ethiopia
}

\author{
Tekleweini Gereslassieㄹ, Ababo Workineh'1, Goitom Takele², Muhamed Adem ${ }^{3}$, \\ Leakemariam Berhe ${ }^{2 *}$
}

\author{
${ }^{1}$ Department of Pollution Ecology, Institute of Wuhan Botanical Garden, University of Chinese Academy of Sciences (UCAS), \\ Wuhan, China \\ ${ }^{2}$ Department of Forestry, Wondogenet College of Forestry and Natural Resources, Hawassa University, \\ Shashemene, Ethiopia \\ ${ }^{3}$ Department of Forestry, College of Agriculture and Natural Resources, Madawalabu University, \\ Bale Robe, Ethiopia \\ Email: ^tekle206@gmail.com
}

How to cite this paper: Gereslassie, T., Workineh, A., Takele, G., Adem, M., \& Berhe, L. (2019). Total Volume and Aboveground Biomass Models for Juniperus procera Plantation in Wondo Genet, Southern Ethiopia. Open Journal of Forestry, 9, 89-108. https://doi.org/10.4236/ojf.2019.92004

Received: January 21, 2019

Accepted: March 17, 2019

Published: March 20, 2019

Copyright (c) 2019 by author(s) and Scientific Research Publishing Inc. This work is licensed under the Creative Commons Attribution International License (CC BY 4.0).

http://creativecommons.org/licenses/by/4.0/

\section{Open Access}

\begin{abstract}
Species specific allometric equations are important for estimation and quantification of net volume and aboveground biomass of living trees. This study was basically focused on fitting total volume and aboveground biomass models for Juniperus procera plantations in Wondo Genet, Sidama Zone, Ethiopia. Data for fitting the total volume and aboveground biomass models were obtained by destructively sampling of trees from the ten diameter classes of the Juniperus procera plantation in the study area. A total of one hundred ten and fifty-one trees were destructively sampled to fit six total volume and six aboveground biomass models respectively. After important measurements of parameters have completed, model performance evaluation and selecting of best fit models were undertaken using standard error of estimates (SEE), coefficient of determination $\left(R^{2}\right)$, bias $(B)$ and mean of the absolute value of errors (MAE). Accordingly, the total volume model $V t=-5.466+0.959 \mathrm{Dbh}^{0.005} \mathrm{H}^{003}$ and aboveground biomass model of $B=0.348 \mathrm{Dbh}^{0.57} \mathrm{H}^{0.032}$ were found to be the best predictive models for total tree volume and aboveground biomass respectively. In addition to the above results, diameter at breast height and total tree height data obtained from 69 circular sample plots of 0.01 ha area drawn from the plantation were used to estimate the total volume and aboveground biomass per hectare $B E F$ which was estimated to be $0.64 \mathrm{Mg} / \mathrm{m}^{3}$. Generally, the selected models and computed BEF in this study are believed to be applied by different organisations and researches to estimate the total volume and aboveground biomass of the J. procera.
\end{abstract}




\section{Keywords}

Biomass Expansion Factor, Biomass Models, Total Volume Models, Juniperus procera

\section{Introduction}

Forests play a significant role in sustaining economy, ecology and social development and growth (Chakravarty et al., 2011). The ecological function and economic values of forests, which often expressed in terms forest biomass and volume, require a reliable method of estimation (Djomo et al., 2010; Günlü et al., 2014). Direct measurement of volume and biomass in most cases gives a reasonable accuracy, however, employing field measurement especially in large-scale plantation projects is quite expensive, labour-intensive, mostly destructive, time-consuming and sometimes impracticable (Li \& Xiao, 2007; Ounban et al., 2016). Thus, estimation of volume and biomass using allometric equations which can represent the field measurement for large-scale industrial plantations is highly advisable (Lehtonen et al., 2004; Zianis et al., 2005; Oyamakin, 2011). Forest growth models have the ability of describing the development of tree crops with specific time changes, species and sites (Hjelm, 2015). There are various types of forest models including tapper model, crown models, however, total tree volume and biomass models are the commonly applied models in forest management planning, estimating the forest volume, tree biomass, carbon content and evaluating the ecological roles forests (Akindele \& LeMay, 2006; Berhe, 2009).

Unlike early efforts of individual tree and stand volume estimations which follow destructive method, recent research works use allometric equations constructed from easily measurable tree parameters, mainly diameter at breast height (Dbh) and total height (H) (Yohannes, 2002; Akindele \& LeMay, 2006; Zhao et al., 2016). Allometric equations are the cost-effective methods of estimating the economic and ecological values of both natural and plantation forests (Lehtonen et al., 2004; Kebede \& Soromessa, 2018). Moreover, both volume and biomass data are the principal input to predict the status of forest and designing appropriate silvicultural interference (Fox, 2000; Gregoire \& Köhl, 2000; Foli et al., 2003; Ezenwenyi et al., 2018). The other merits of using allometric equations are their ability to reflect the actual estimation of total carbon and biomass of the stand including the un-merchantable components of the forests, particularly trees (Gómez-García et al., 2014). Reliable information about total tree volume and biomass is fundamental input to assess site productivity, carbon sequestration and overall sustainability of an ecosystem (Djomo et al., 2010). Total tree volume and aboveground biomass equations are recently considered as the central objectives of forest inventory, carbon stock monitoring and management plans (Brandeis et al., 2006; Subasinghe, 2008). In addition to the diameter at 
breast height and total tree height, some allometric equations employ form factor to estimate total stem volume; however, inclusion of form factor has less practical advantage (Yohannes, 2002; Hjelm, 2011). Thus, the common expression of tree volume as a function of diameter at breast height (outside bark) and tree height was used for this study (Mugasha et al., 2016).

$$
V=f(\mathrm{Dbh}, \mathrm{H})
$$

where: $V=$ Total volume, $\mathrm{Dbh}=$ Diameter at breast height and $\mathrm{H}=$ Total height.

To date, estimations of aboveground biomass especially tropical forests have received much attention and considered as a principal component of forest management (Brown, 2002; Chave et al., 2005; Yitebitu et al., 2010). As a result, many researchers use different approaches to estimate the biomass accumulated in a given forest. Apart from allometric equations and direct measurement, conversion of national inventory data to aboveground biomass is possible through the two distinctive approaches (Chave et al., 2013). The first approach used for species with known merchantable volume is through application of simple models employing biomass expansion factors (Brown, 2002). However, the high dependency of BEF on species growth characteristics and lack of timely updated data in most tropical countries national forest inventory are the two bottlenecks of using biomass expansion factor (Brown, 2002; Dutcă et al., 2010). The second and more general approach of estimating aboveground biomass from national inventory data obtained from satellites, remote sensing, aerial photography is normalized difference vegetation index (NDVI) (Van Breugel et al., 2011; Günlü et al., 2014). Biomass estimation using NDVI is relatively less accurate, subjective and biased (Brown, 2002; Dutcă et al., 2010). BEF is expressed as:

$$
\mathrm{BEF}=\frac{B}{V}
$$

where: $B=$ Aboveground biomass (dry weight), $V=$ Total volume.

It is noteworthy that the use of allometric biomass regression equations is time and resources efficient method to estimate the biomass accumulated in large-scale industrial plantations (Delitti et al., 2006; Somogyi et al., 2008). There is no universally accepted allometric equation to estimate volume and biomass of trees; thus, allometric equations used for different species and sites are not the same (Berhe, 2009; Worku \& Soromessa, 2015). Mixed species tree biomass regression models is applicable for most diverse tropical forests, however, the results of mixed regression models are less accurate and hardly represent all species in the forest (Chave et al., 2005). Therefore, species specific allometric equations can better estimate the volume and biomass of a given plantation species and other species of similar growth characteristics (Worku \& Soromessa, 2015).

Plantation forests constitute a significant share of forest resources cover and sequestered considerable amount of carbon in Ethiopia (Yitebitu et al., 2010). Though quantification of volume and biomass of forest plantations is vital; previous attempts to develop tree volume and biomass allometric for plantation 
species in Ethiopia (especially indigenous trees species) are inadequate (Henry et al., 2010; Tesfaye et al., 2016). Like many indigenous trees there is lack of predictive allometric equation for the total volume and aboveground biomass of $J$. procera plantations in Wondo genet, Sidama Zone, Southern Nations, Nationalities and Peoples' Region, Ethiopia. Development species specific allometric equations is crucial in view of the fact that reliable information, precise quantification and projection of stand level total volume and aboveground biomass in the study site and other places with similar agro-ecological and species types are important. Therefore, focus of the paper is to develop and select best fit total volume and aboveground biomass allometric equations and estimating the biomass expansion factor for $J$. procera plantations in Wondo genet.

\section{Materials and Methods}

\subsection{Species Description}

Juniperus procera is naturally found in the central highlands of Ethiopia, mainly between altitudes of $2300-3200 \mathrm{~m}$ a s 1 , with an annual rainfall range that varies between 450 and 1200 millimetres (Couralet et al., 1992). It is an indigenous conifer species found in Ethiopia It is locally named as "Tid" and commercially known as "African Pencil Cedar" (Berhe \& Negash, 1998). This tree has been a very important source of wood for timber and fuel with minimum demand on land (Gibbs et al., 2007). Its wood is fragrant, fine in texture with strait grain and highly resistant to termites as well as fungal diseases. Because of these distinctive qualities, it is considered as one of the high quality wood for construction of houses, internal structures of churches, furniture and for poles (Couralet et al., 1992). It is an evergreen deciduous, more seldom monoecious tree, which belongs to the family of Cupressaceae and genus Juniperus. It is the tallest juniper tree in the world with two developmental phases, the juvenile and the adult stage (Gibbs et al., 2007). On the adult stage it is characterized by distinctive trunk and crown shapes extend up to $45 \mathrm{~m}$ height (Couralet et al., 1992; Berhe \& Negash, 1998). It has male and female cones, male cones are small and round; while the female cones are berry-like rounded that becomes fleshy upon ripening (Carreiras et al., 2017). This tree's flower and give fruits produces 40,000 - 50,000 seed per kilogram $(\mathrm{kg})$ with germination rate of $20 \%-70 \%$ throughout the year without an interrupting resting stage (Gibbs et al., 2007).

\subsection{Site Description and Stand Selection}

Samples were collected from plantation sites on July 2018 from southeast of Shashemene, Wondo Genet, Southern Ethiopia. It is located in $7^{\circ} 13^{\prime} \mathrm{N}$ and $38^{\circ} 37^{\prime} \mathrm{E}$, about $263 \mathrm{Km}$ south of Addis Ababa and $13 \mathrm{Km}$ east of Shashemene, at an altitude of $1800-2100 \mathrm{~m}$. The study site is characterized by a bimodal pattern of precipitation with an annual average of $1200 \mathrm{~mm}$, where a short rainfall period runs from March to April with a long rainfall period covers from June to September and a dry period extends from December to February. The study area 
is one of the most productive agricultural lands in Ethiopia with a good access to irrigation water supply from the upper catchments and ideal temperature ranging from $19^{\circ} \mathrm{C}-25^{\circ} \mathrm{C}$. It is known for the production of cash crops such as Saccharum officinarum, Coffea arabica and Cata eduli $s$ and natural and plantation forests. To simplify the sampling procedure, a management plan and map of the plantation were used as a tool to locate each compartment and compiled the history of the compartments. The management plan provided all the required site information about the available species in the plantation area. Accordingly, Cupressus Iusitanica, Eucalyptus citriodora, Eucalyptus grandis, Grevillea robusta, J. procera, Pinus patula, Pinus radiate, Podocarpuse falcatus and others are among the dominant tree species. J. procera covers about $7.6 \%$ of the total plantation area, which makes it the widely growing indigenous tree species in the study area.

\subsection{Data Collection}

\subsubsection{Tree Volume Data}

Sample trees for volume estimation were taken from all diameter classes after the diameter distribution of each stand has recorded from a 5.64-meter radius circular plots laid using systematic random sampling (Mugasha et al., 2016). Diameter at breast height measurements from 69 sample plots to determine the Dbh distribution of the across all compartments and grouped into 10 diameter classes in way to accommodate the variability of tree diameter (Worku \& Soromessa, 2015). Altogether, one hundred ten sample trees from all diameter classes were selected and felled for further measurements. Diameter at breast height, stamp height $(0.2 \mathrm{~m}), 0.35 \mathrm{~m}, 0.5 \mathrm{~m}, 0.65 \mathrm{~m}, 0.8 \mathrm{~m}$ and $1 \mathrm{~m}$ were measured before felling. To get sufficiently reliable data the diameter over bark at a one-meter interval from Dbh to the top of the tree and total height were measured after felling using Caliper and meter tape respectively (Berhe, 2009). Diameter records were taken by cross-calipering along the axis of the tree bole. The total tree and log volume between consecutive diameter measures was calculated using Smalian's formula, while cone formula was used to compute the top stem section volume.

$$
\begin{gathered}
V(\text { co })=\frac{\pi D^{2}}{12} \times L \\
V(\text { cy })=\frac{\pi D^{2}}{4} \times L \\
V(\log )=\frac{\pi}{8} \times\left(D 1^{2}+D 2^{2}\right) \times L
\end{gathered}
$$

The Dbh distribution, frequency and the sample trees felled for tree volume estimation are presented in Table 1 . While the minimum, maximum, mean and standard deviation values for total volume, Dbh and tree height are depicted in Table 2 . 
Table 1. Frequency and diameter class of sample trees for biomass data.

\begin{tabular}{ccc}
\hline Class & Diameter Class $(\mathrm{cm})$ & Frequency \\
\hline 1 & $4.3-7$ & 6 \\
2 & $7.1-9.5$ & 13 \\
3 & $9.6-11.5$ & 12 \\
4 & $11.6-13.5$ & 16 \\
5 & $13.6-15.5$ & 16 \\
6 & $15.6-17.5$ & 16 \\
7 & $17.6-19.5$ & 11 \\
8 & $19.6-22.5$ & 10 \\
9 & $22.6-25.5$ & 5 \\
10 & $25.5-30.5$ & 5 \\
& Total sample trees & 110 \\
\hline
\end{tabular}

Table 2. Summary of volume data.

\begin{tabular}{cccc}
\hline Statistics & Dbh $(\mathrm{m})$ & $\mathrm{H}(\mathrm{m})$ & $V_{i}\left(\mathrm{~m}^{3}\right)$ \\
\hline Min & 0.046 & 4.7 & 0.008 \\
Max & 0.318 & 24 & 1.907 \\
Mean & 0.151 & 14.4 & 0.327 \\
Sd. & 0.055 & 3.27 & 0.099 \\
\hline
\end{tabular}

where: $\mathrm{Dbh}=$ diameter at breast height, $\mathrm{H}=$ total height, $\mathrm{Sd}=$ standard deviation, $\min =$ minimum, $\max =$ maximum, Sd. = standard deviation, $V_{i}=$ individual tree volume.

\subsubsection{Tree Biomass Data}

Fifty-one of the total one hundred felled sample trees for volume were considered for biomass measurement. Nearly five sample trees from each compartment were considered for biomass. Following similar procedure to tree volume samples, the diameter over bark and total height of the tree was measured and sub-divided into three components stem, branch, and foliage. Then, three sub-samples were taken from each respective tree components. The total green weight of stems, branches, and foliage components was determined directly in the field using beam balance of $100 \mathrm{~kg}$ capacity. The field fresh weights of all components were summed up to obtain aboveground fresh weight of each tree. The minimum, mean and maximum fresh weights of the stem were $36,85.25$ and $137 \mathrm{~kg}$ respectively. While the minimum, mean and maximum values were 6,31 and $56 \mathrm{~kg}$ for branch and, 5.5, 13.5 and $23 \mathrm{~kg}$ for leaf samples respectively. The frequency distribution of the sample trees taken for biomass models are summarized in Figure 1.

To determine the dry weight of the trees, representative sub-samples were taken from the dissected tree components (stem, branches, and foliage) were taken to laboratory for dry weight determination. Accordingly, three stem disc sub-samples were taken from stump height at $20 \mathrm{~cm}$, Dbh $(1.3 \mathrm{~m})$ and $50 \%$ (half) of 


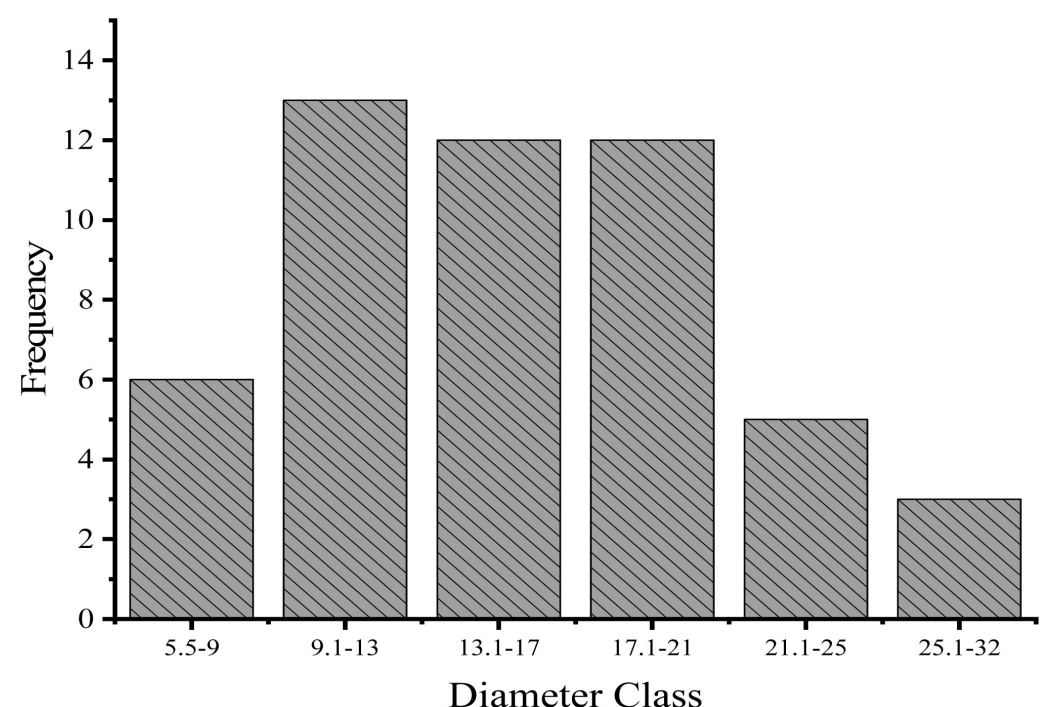

Figure 1. Distribution of diameter at breast height of sample trees for biomass data.

the total stem length. Finally, a total of 153 stem sub-samples were taken for determination of stem dry weight and moisture. Branch samples were grouped into three classes (small, medium and large) by size. One branch disc was taken from the live crown of each branch group. A total of 153 branch sub samples (discs) were taken for further measurements. For foliage samples, overall 102 foliage sub-samples were taken for laboratory dry-weight analysis. After immediate labelling and coding with respect to component, sub-samples of each component were sealed in plastic bags, and taken to a laboratory for weight measurement. Fresh weight of sub-sample component was uniformly weighed with electrical digital scale balance (with a precision of $+-/ 0.1 \mathrm{~g}$ ), and liable to air drying for approximately 7 days (Gibbs et al., 2007). The stem and branch discs were oven dried at $105^{\circ} \mathrm{C}$, while leaf samples are oven dried at $70^{\circ} \mathrm{C}$ until constant weight has recorded. The summary of dry to fresh weight ratio of sub-samples is given in Table 3.

\subsection{Model Selection and Evaluation}

Considering the essential role of allometric equations in predicting the total volume, biomass, evaluating the ability of sinking atmospheric carbon dioxide $\left(\mathrm{CO}_{2}\right)$ and greenhouses, several research works have been published and applied for centuries (Fox, 2000; Chave et al., 2005; Gibbs et al., 2007). Validation of tree volume and biomass equations were essential in predicting the forest dynamics, socio-economic values, global trends of climate change and estimation of carbon sequestration (Ribeiro et al., 2011; Carreiras et al., 2017). Both total tree volume and models biomass regression equations use diameter at breast height and total tree height to predict the aboveground biomass accumulated in a given forest (Dutcă, 2018). Measurement of independent variables used to predict tree volume and biomass should be free measurement error, however error free measurement of variables is hardly practicable and might lead to under or 
Table 3. Summary of dry to fresh weights ratio of sub-samples.

\begin{tabular}{cccc}
\hline \multirow{2}{*}{ Values } & \multicolumn{3}{c}{ Sub-samples dry to fresh weight ratio } \\
\cline { 2 - 4 } & Foliage & Branch & Stem \\
\hline Minimum & 0.533 & 0.449 & 0.499 \\
Maximum & 0.451 & 0.458 & 0.514 \\
Mean & 0.499 & 0.471 & 0.455 \\
Sd. & 0.034 & 0.023 & 0.034 \\
\hline
\end{tabular}

over estimation of the dependent variables (Arias-Rodil et al., 2018). Thus, dealing with the best predictive equations in a way to minimise the measurement errors is highly advisable. Though total tree volume and aboveground biomass equations are several and are site and species specific, we analysed the most frequent and possibly most predictive allometric equations used by previous researchers (Vieira et al., 2008; Table 4).

Comparison of the regression models were carried out by using statistical values computed directly from entire data sets (Kozak \& Kozak, 2003). Statistics such as bias $(B)$, standard error of estimates (SEE), an average absolute value of the error $(\mathrm{ABE})$ and estimated coefficient of determination $\left(R^{2}\right)$ are the commonly applied statistics to evaluate the model performance and select the best fit equations (Segura \& Kanninen, 2005; Lumbres et al., 2011). Other literature also employed $B$, SEE, $R^{2}, \mathrm{AB}$ and $\mathrm{SD}$ as performance evaluation for taper models (Berhe, 2009; Ezenwenyi et al., 2018) and above- and belowground biomass of selected species (Kalita et al., 2015). Similarly, the performance the selected models fitted to volume and biomass data in this study was evaluated using those four commonly used performance statistics: bias $(B)$, standard error of estimates (SEE), mean absolute value of the error (MAE) and estimated coefficient of determination $\left(R^{2}\right)$. All the performance statistics used are defined below.

$$
\begin{gathered}
B=\frac{\sum_{i=1}^{n} y_{i}-\hat{y}_{i}}{n} \\
\mathrm{MAE}=\frac{\sum_{i=1}^{n}\left|y_{i}-\hat{y}_{i}\right|}{n} \\
\mathrm{SEE}=\sqrt{\frac{\sum_{i=1}^{n}\left(y_{i}-\hat{y}_{i}\right)^{2}}{n-k}} \\
R^{2}=1-\frac{\sum_{i=1}^{n}\left(y_{i}-\hat{y}_{i}\right)^{2}}{\sum_{i=1}^{n}\left(y_{i}-\bar{y}\right)^{2}}
\end{gathered}
$$

where: $y_{i}=$ observed response variable value, $\hat{y}_{i}=$ estimated response variable value, $\bar{y}=$ mean value of response variable, $n=$ number of observation, $i$ = number of estimated parameters, $n=$ number of trees, $k=$ number of estimated parameters.

Total tree volume and aboveground biomass equations with highest coefficient of determination $\left(R^{2}\right)$ value, lowest bias, SE and MAE were selected as 
Table 4. Total volume and aboveground biomass equations.

\begin{tabular}{|c|c|c|}
\hline$\#$ & Volume equations & Reference \\
\hline 1 & $V t=\beta_{1} \mathrm{Dbh}^{\beta 2}+\beta_{3} \mathrm{H}^{2}+\beta_{4} \mathrm{DbhH}^{2}$ & (Hjelm, 2011; Hjelm, 2015) \\
\hline 2 & $V t=\beta_{1} \mathrm{Dbh}^{\beta 2} \mathrm{H}^{\beta 3}$ & (Berhe, 2009) \\
\hline 3 & $V t=\alpha+\beta_{1} \mathrm{Dbh}^{2}+\beta_{2} \mathrm{H}^{\beta 3}$ & (Akindele \& LeMay, 2006) \\
\hline 4 & $V t=\alpha+\beta_{1} \mathrm{Dbh}^{2} \mathrm{H}$ & (Kozak \& Kozak, 2003) \\
\hline 5 & $V t=\beta_{1} \mathrm{Dbh}^{2}+\beta_{2} \mathrm{Dbh}^{2} \mathrm{H}+\beta_{5} \mathrm{DbhH}^{2}-\beta_{3} \mathrm{Dbh}^{2} \mathrm{H}^{2}-\beta_{4} \mathrm{DbhH}$ & (Hjelm, 2011) \\
\hline \multirow[t]{2}{*}{6} & $V t=\beta_{1}+\beta_{2} \mathrm{D}^{\beta 3} \mathrm{H}^{\beta 4}$ & (Segura \& Kanninen, 2005) \\
\hline & Aboveground biomass equations & Reference \\
\hline 1 & $B=\beta_{1} \mathrm{Dbh}^{\beta 2} \mathrm{H}^{\beta 3}$ & (Kozak \& Kozak, 2003) \\
\hline 2 & $B=\beta_{1} \mathrm{Dbh}^{2}+\beta_{2}(\mathrm{DbhH})^{2}$ & (Chave et al., 2005) \\
\hline 3 & $B=\exp \left(\beta_{1}+\beta_{2} \log \left(\mathrm{Dbh}^{2} \mathrm{H}\right)\right)$ & (Chave et al., 2005) \\
\hline 4 & $B=\alpha+\beta_{1}\left(\mathrm{Dbh}^{2} \mathrm{H}\right)$ & (Lumbres et al., 2011) \\
\hline 5 & $\log (B)=\alpha+\beta_{1} \log (\mathrm{Dbh})+\beta_{2} \log (\mathrm{H})$ & (Zhao et al., 2016) \\
\hline 6 & $B=\beta_{1} \mathrm{Dbh}+\beta_{2} \mathrm{Dbh}^{2}$ & (Vieira et al., 2008) \\
\hline
\end{tabular}

where: $V t=$ stem volume in $\mathrm{m}^{3}, B=$ aboveground biomass, $\mathrm{H}=$ total height $\mathrm{Dbh}=$ diameter at breast height and $\alpha, \beta_{1}, \beta_{2}, \beta_{3}, \beta_{4}$ and $\beta_{5}=$ model parameters.

best-fit models. After ranking of each performance statistics for all allometric equations, the final ranking was accomplished by summing up the ranks for the four computed performance statistics. Equations with lower sum of ranks were selected as best fit allometric models to predict the total volume and biomass models (Berhe, 2009).

\subsection{Data Analysis}

All computations and analysis for this study were carried out using IBM SPSS statistics version 20 . The linear and none-linear models listed in above were fitted to estimating total volume and aboveground biomass using the linear and multiple regression equations at a significance level of 0.05 .

\section{Result and Discussion}

The result and discussion part of this paper presents findings of the research with respect to the designed research objectives. Therefore, this part includes an estimated total stand and individual tree volume and aboveground biomass, fitting of models for estimating volume, of aboveground biomass, comparing biomass estimates computed from developed biomass model for J. procera and the computed biomass expansion factor.

\subsection{Total Volume}

The initial stage of analysing and actual processing of data for developing the best fit total volume models, the graphical illustration of the relationship between total tree volume and potential predictors of the one hundred ten sample 

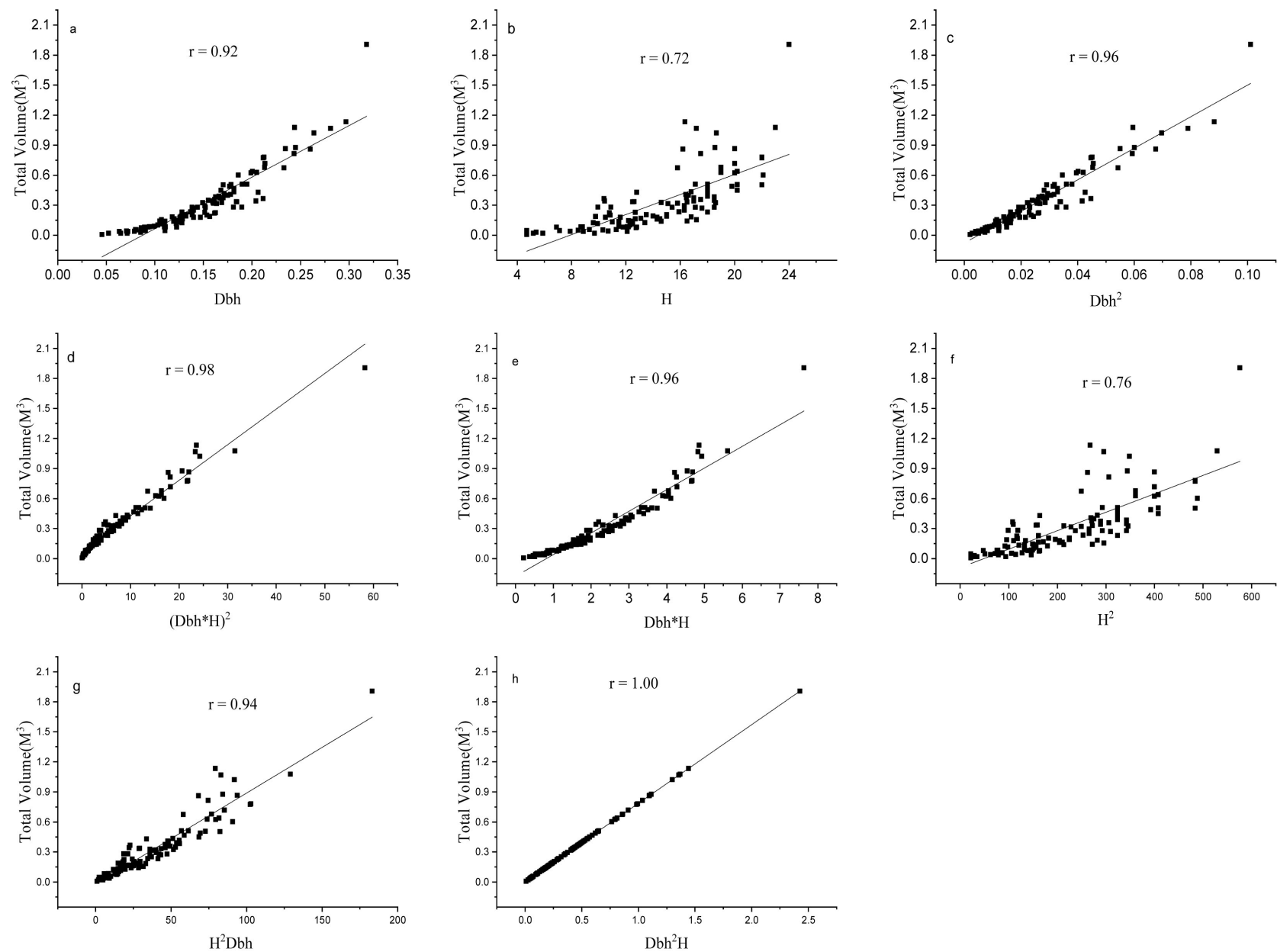

Figure 2. Scatter plot of total volume versus potential predictors. 
Table 5. Volume model performance statistics and their rank in parenthesis.

\begin{tabular}{|c|c|c|c|c|c|c|c|c|c|c|c|}
\hline \multicolumn{12}{|c|}{ Total volume modes } \\
\hline \multirow{2}{*}{$\#$} & \multicolumn{6}{|c|}{ Parameter of estimates } & \multicolumn{5}{|c|}{ Performance statistics } \\
\hline & $A$ & $\beta_{1}$ & $\beta_{2}$ & $\beta_{3}$ & $\beta_{4}$ & $\beta_{5}$ & $R^{2}$ & SEE & Bias & MAE & Rank \\
\hline 1 & - & -5.466 & 0.959 & 0.005 & 0.003 & & $0.993(3)$ & $0.0007(3)$ & $0.0142(5)$ & $0.0207(1)$ & $12(3)$ \\
\hline 2 & & -1.537 & 3.954 & -5.455 & - & - & $0.887(6)$ & $0.0179(6)$ & $0.0560(6)$ & $0.1229(6)$ & $24(6)$ \\
\hline 3 & -0.20 & 0.002 & 7.473 & -10.29 & - & - & $0.963(4)$ & $0.0034(4)$ & $0.0002(1)$ & $0.0590(4)$ & $13(4)$ \\
\hline 4 & -0.059 & 0.0001 & - & - & - & - & $0.914(5)$ & $0.0079(5)$ & $-0.0003(2)$ & $0.0864(5)$ & $17(5)$ \\
\hline 5 & - & 0.001 & 0.0002 & 0.0000011 & 0.001 & -0.00005 & $0.995(2)$ & $0.0004(2)$ & $0.0017(3)$ & $0.0209(3)$ & $10(2)$ \\
\hline 6 & & 0.0002 & 7.8571 & 3.000 & 0.00004 & - & $0.997(1)$ & $0.0002(1)$ & $0.0026(4)$ & $0.0134(2)$ & $8(1)$ \\
\hline
\end{tabular}

estimates (SE), mean absolute error (MAE) and coefficient of determination $\left(R^{2}\right)$ for all candidate models were ranked according to their performance of each computed statistics and their ability to estimate the total tree volume. Final rank of the compared models was determined by summing up the performance of each model with respect to the chosen statistical measures at $p$-value $=$ 0.05 .

According to the above results, all of the allometric volume equations are highly significant at an alpha level of 0.05 with explaining potential of $\geq 88 \%$ total volume variation; the obtained results were similar to the research result presented from urban trees in the north-eastern USA (Troxel et al., 2013). The last column of Table 5 shows the rank of the models. Previous studies ascertained that allometric equations are specific to species and site; however, models with less bias, high coefficient of determination, less standard error and mean square error are best estimator models (Chave et al., 2005; Cole \& Ewel, 2006; Berhe, 2009). Accordingly, model six (6) followed by model five (5) yields the smallest sum of the ranks, hence; model six (6) outperforms the rest of the models and selected as the best total volume models. To clearly identify the performance of models having equal variances standardized residual were plotted against the predicted volume (Akindele \& LeMay, 2006). The standardized residual versus fitted volume scatter plot; estimated from both the least squares method and generalized least squares method indicate even distribution of observations. The results obtained for this study in lines with the remarks given by other works (Berhe, 2009; Kozak \& Kozak, 2003). Particularly, the estimated and residual volume of Cupressus lusitanica and Pinus patula plantations in Ethiopia using model two (2) was clearly presented by (Berhe, 2009). The observed against estimated volume constructed for this study is presented in Figure 3.

\subsection{Aboveground Biomass}

\subsubsection{Descriptive Analysis}

The ratio of oven dry weights to field fresh weights of the tree components (stem, root, braches and leaves) employed to estimate the total biomass of trees 


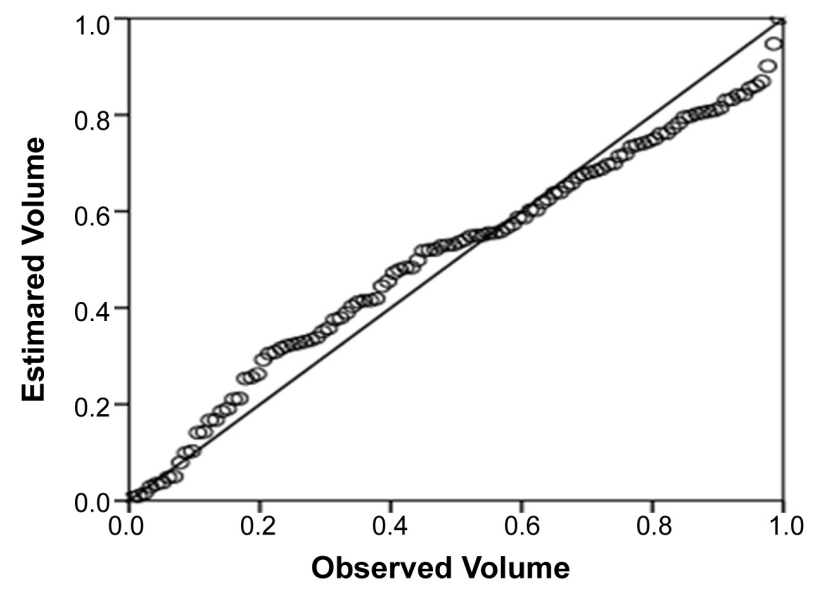

Figure 3. The scattered plot for estimated and observed total tree volume.

were computed. Hereafter, the total aboveground biomass was obtained by summing the stem, branch and leaf dry weights (Ounban et al., 2016). To validate the aboveground biomass allometric equations, the relationships between tree dry weights and potential predicting parameters were evaluated. The results displayed in Figure 4 indicated that aboveground biomass exhibits nonlinear relationship with $\mathrm{H}$ and $\mathrm{H}^{2}$. However, aboveground biomass exhibits a strong linear and linear relationship with $\mathrm{Dbh}$ and $\mathrm{Dbh}^{2}$, respectively at a $95 \%$ confidence intervals; this result in line with the research result presented by (Delitti et al., 2006; Van Breugel et al., 2011; Ounban et al., 2016). A significant increase in biomass accumulation was observed with increasing diameter of the trees.

The proportion of aboveground biomass varies with tree components (stem, branches, and foliage) Figure 5. The mean proportion of aboveground biomass by tree component was estimated to be $50.1 \%$ (foliage), $47.4 \%$ (branch) and $45.5 \%$ (stem). The overall average dry to fresh-weight ratio was approximately $45.7 \%$. The dry to fresh-weight ratio approximately estimated to be $47.7 \%$. The average dry to fresh-weight ratio was higher for foliage than the branch and stem components.

According to previous research works, belowground biomass of trees estimated to be approximately one-fifth (20\%) of the aboveground biomass (Pearson et al., 2005; Giri et al., 2014). Thus, predicting the belowground biomass (BGB) from the aboveground biomass is more time and resource saving approach (Worku \& Soromessa, 2015). Therefore the belowground biomass in was estimated as follows:

$$
\mathrm{BGB}=\mathrm{AGB} \times 0.2
$$

where: $\mathrm{BGB}=$ belowground biomass, $\mathrm{ABG}=$ aboveground biomass.

\subsubsection{Fitted Biomass Models}

Even though there are a lot of biomass equations used to estimate below and aboveground components of plants, few allometric equations used by (Zianis \& Mencuccini, 2004; Mulat \& Soromessa, 2016) are the commonly used models to 

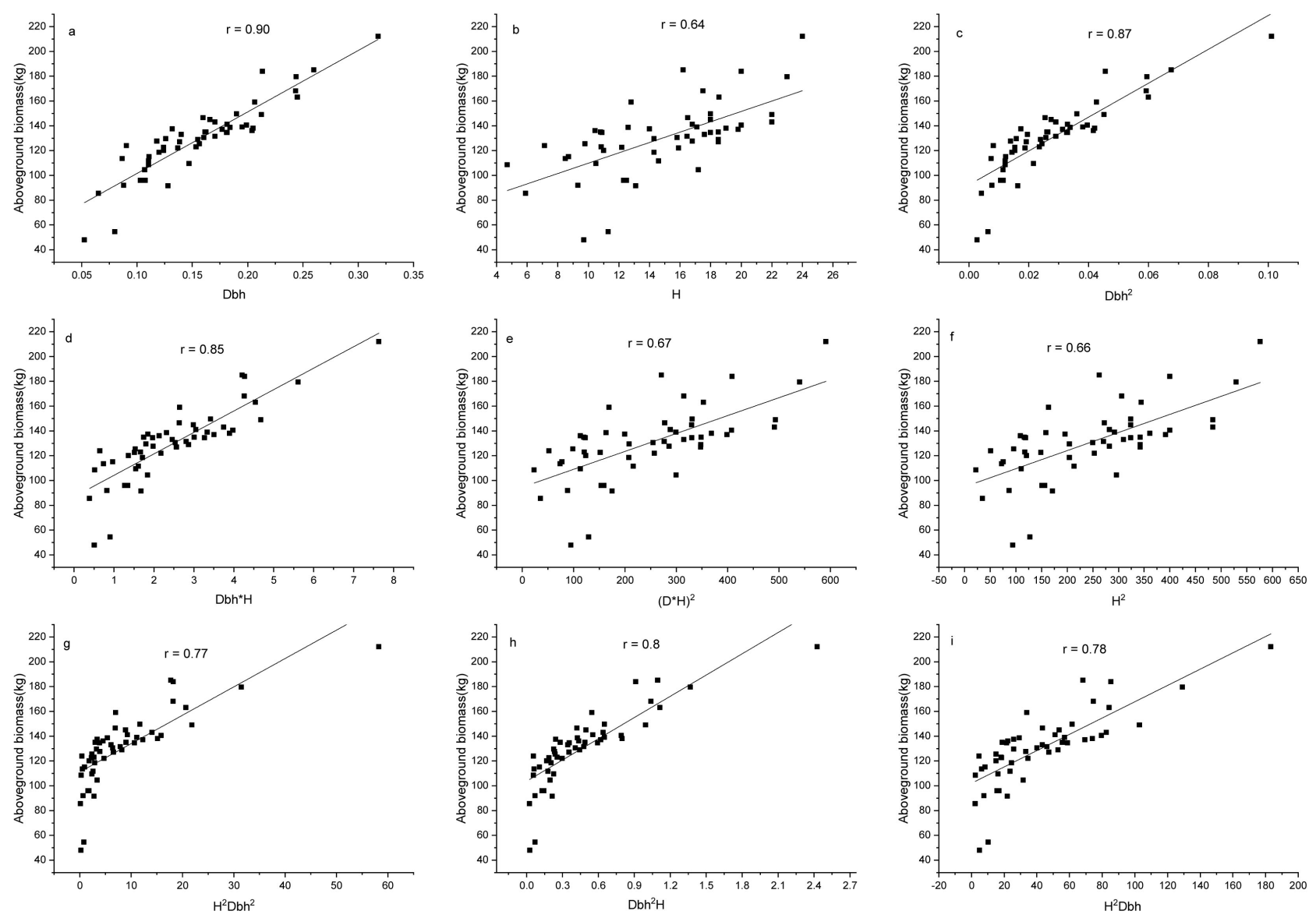

Figure 4. Relationship of aboveground biomass and potential predictors.

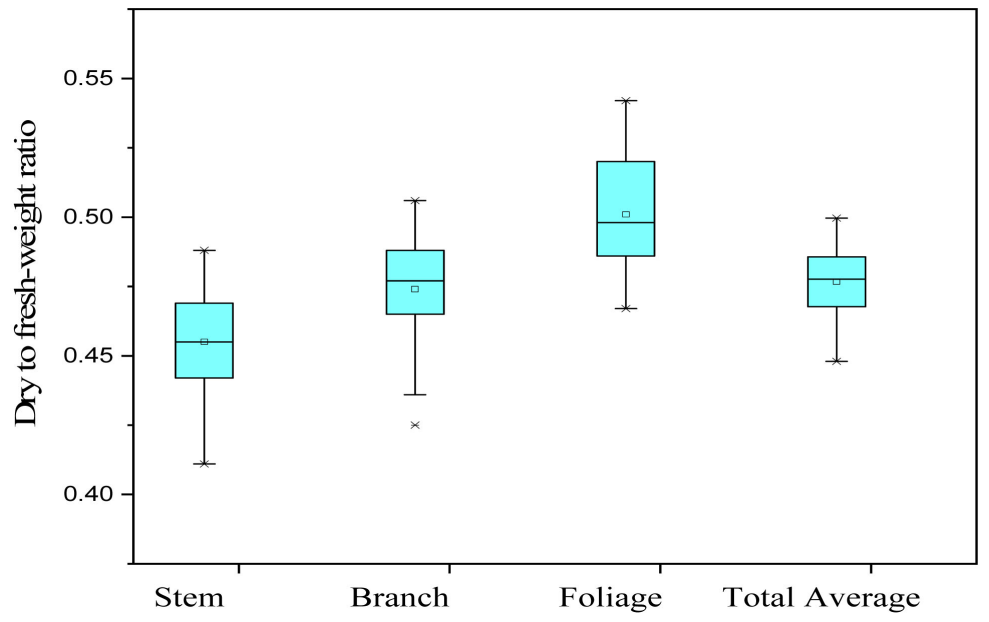

Figure 5. Proportion of aboveground biomass tree components.

estimate biomass of different tree components stem, branch, leaf, and root. Though, Zianis and Mencuccini (2004) stated that site fertility, elevation, soil type diameter at breast height and total tree height are some of the common variables used in fitting biomass estimation equations, only diameter at breast height and height were applied in this study. Thus, six commonly used models 
applied and developed by (Zianis \& Mencuccini, 2004; Chave et al., 2005; Zianis et al., 2005; Siregar, 2011; Brown, 2015) were employed for this study. The fitted biomass models and their parameter estimates are presented in Table 6.

Similar to the procedures followed in fitting volume models, the four performance statistics were computed for biomass models. Results displayed in $\mathrm{Ta}$ ble 6 indicated that all the allometric equations used can well determine the aboveground biomass accumulated in the forest stands. Moreover, the SE and MAE values of all models are close in their values, indicating of the competitive performance of the biomass models. According to the sum of computed performance statistics displayed on the last row of Table 6; model one (1) followed by model three (3) was found as the best models to estimate the aboveground biomass of $J$. procera plantation. Worku and Soromessa (2015) have also applied similar evaluation statistics to select best-fit models to estimate the biomass and carbon accumulated in Podocarpus falcatus in Wof-Washa forest, Ethiopia. These researchers finally conclude that allometric equations are species specific. Generally, applying biomass equations has a big contribution in improving the reliability data on national carbon inventories at a single species level or large scale plantations of similar nature (Jalkanen et al., 2005).

\subsubsection{Biomass Expansion Factor}

Measurement of total tree volume from diameter and total tree height is more direct and easier than determination of biomass. The use of biomass expansion factor which is the ratio of total biomass mega gram $(\mathrm{Mg})$ to total volume $\left(\mathrm{m}^{3}\right)$ is a useful approach to convert the total tree volume accumulated in a given forest stands to biomass (Zhao et al., 2016). There is a possibility of using previously developed BEF by other researcher, however the value obtained are mostly biased due to variability of estimated volume and biomass with species and site (Zhao et al., 2016). Once species specific total volume and biomass models have selected, the expanding stem biomass to whole tree and total biomass accumulated in the forest stands and large-scale plantations forests (Dutcă et al., 2010). Forest inventory data obtained from national and local management plans are the inputs used to calculate the accumulated forest biomass by employing the BEF for each plots. Thus, prediction of biomass is an easy task in a condition total tree volume data is available. In this study, the selected aboveground biomass model one (1) and volume model six (6) were used to estimate biomass and volume of trees obtained from 69 circular plots of $100 \mathrm{~m}^{2}$ area laid across the plantation stands of the $J$. procera plantation. The estimated BEF, total volume $(V)$ and biomass $(B)$ per hectare are presented in Table 7 .

The estimated BEF in this study was approximately similar to the 0.84 for Spruce, 0.74 for Pine and 0.99 for broadleaved dominated stands in Norway (Viken et al., 2012), 0.71 for Scots pine stands, 0.81 for Norway spruce stands spruce and 0.64 for broad-leaved stands based on the Sweden's National Forest (Viken et al., 2012). However, the result of this study was inconsistent with the results of BEF of $2.1 \pm 1.0$ reported for different agroforestry species in subtropical 
Table 6. Fitted aboveground biomass models.

\begin{tabular}{ccccccccccc}
\hline \multicolumn{8}{c}{ Biomass models } \\
\hline$\#$ & \multicolumn{6}{c}{ Parameter of estimates } & \multicolumn{4}{c}{ Performance statistics } \\
\cline { 2 - 9 } & $\boldsymbol{\alpha}$ & $\beta_{1}$ & $\beta_{2}$ & $\beta_{3}$ & $R^{2}$ & SEE & Bias & MAE & Rank \\
\hline 1 & - & 0.348 & 0.57 & 0.032 & $0.963(1)$ & $0.00001(1)$ & $0.0006(1)$ & $0.0099(1)$ & $4(1)$ \\
2 & & 1.731 & 0.0003 & & $0.939(2)$ & $0.0011(4)$ & $0.0196(4)$ & $0.0354(4)$ & $14(3)$ \\
3 & & -2.846 & 0.0894 & & $0.931(4)$ & $1.6101(6)$ & $0.6687(5)$ & $10.808(6)$ & $21(5)$ \\
4 & 0.104 & 0.057 & - & - & $0.890(5)$ & $0.0002(3)$ & $-0.0007(2)$ & $0.0117(2)$ & $12(2)$ \\
5 & & -2.355 & 1.9819 & 0.4807 & $0.938(3)$ & $1.5910(5)$ & $2.2271(6)$ & $4.8840(5)$ & $19(4)$ \\
6 & 1.116 & -1.681 & - & $0.886(6)$ & $0.0001(2)$ & $0.0008(3)$ & $0.0118(3)$ & $14(3)$ \\
\hline
\end{tabular}

Table 7. Biomass expansion factor, estimates total volume and aboveground biomass of $J$. procera plantation in the study area.

\begin{tabular}{cccc}
\hline & BEF $\left(\mathrm{Mg} / \mathrm{m}^{3}\right)$ & $V\left(\mathrm{~m}^{3} / \mathrm{ha}\right)$ & $\boldsymbol{B}(\mathrm{Mg} / \mathrm{ha})$ \\
\hline \multirow{2}{*}{ Mean } & 0.6488 & 123.9595 & 77.7273 \\
SE & 0.0067 & 8.5352 & 4.8161 \\
\hline
\end{tabular}

region of Yassica Sur district (Segura et al., 2006) and $1.6 \pm 0.2$ for tropical humid forest in Costa Rica (Segura \& Kanninen, 2005). The variation in the BEF obtained in this study has strengthen the argument about BEF is site and species dependent. The predicted belowground biomass was approximately 15.5455 mega gram per hectare $(\mathrm{Mg} / \mathrm{ha})$.

\section{Conclusion and Recommendation}

Results of this study indicated the possible application of allometric equations for prediction of total volume and aboveground biomass of plantations. In particular case, total volume model $V t=b_{1}+b_{2} \mathrm{D}^{b 3} \mathrm{H}^{b 4}$ and aboveground biomass model $B=\beta_{1} \mathrm{Dbh}^{b 2} \mathrm{H}^{\beta 3}$ were selected as the best fitted equations to estimate the total volume and aboveground biomass of J. procera plantation. These selected models provide consistent estimations and logical relationships of $\mathrm{Dbh}$ and $\mathrm{H}$ with the total volume and aboveground biomass. The obtained results also revealed models selected for biomass estimation of both total volume and biomass were different from the previously used equation to estimate in other place and other species, which revealed the inconsistency of models with species and site. These models are believed to be applied by different organisations such as national carbon monitoring centre and academicians to estimate the total volume and biomass of the $J$. procera and species of similar nature in and out of the study site. As the values estimated by BEF and direct measurements are much closer to each other, application of BEF for AGB estimation without destructing trees is thought to be the best alternative option. This doesn't mean that validation of equations and BEF with local data is not required. Though tapper and canopy cover models are equally important, the financial and time limitations 
limited this study to address them. Therefore, future studies should address these gaps. Finally, the researcher would like to suggest that difficulties associated with forest inventory could be minimized; if such models are developed for all other highly valuable indigenous tree species in Ethiopia.

\section{Acknowledgements}

The author is grateful to Wondo Genet College of Forestry for financial support and allowing us to cut trees for data collection from their plantation, carrying out laboratory measurements and other facilities including transportation during field data collection.

\section{Conflicts of Interest}

The authors declare no conflicts of interest regarding the publication of this paper.

\section{References}

Akindele, S. O., \& LeMay, V. M. (2006). Development of Tree Volume Equations for Common Timber Species in the Tropical Rain Forest Area of Nigeria. Forest Ecology and Management, 226, 41-48. https://doi.org/10.1016/j.foreco.2006.01.022

Arias-Rodil, M., Diéguez-Aranda, U., \& Burkhart, H. E. (2018). Effects of Measurement Error in Total Tree Height and Upper-Stem Diameter on Stem Volume Prediction. Forest Science, 63, 250-260 https://academic.oup.com/forestscience/article-abstract/63/3/250/4583990 https://doi.org/10.1007/s00442-005-0100-x

Berhe, D., \& Negash, L. (1998). Asexual Propagation of Juniperus procera from Ethiopia: A Contribution to the Conservation of African Pencil Cedar. Forest Ecology and Management, 112, 179-190. https://doi.org/10.1016/S0378-1127(98)00327-2

Berhe, L. (2009). Volume and Implicit Taper Functions for Cupressus lusitanica and Pinus patula Tree Plantations in Ethiopia. Ethiopian Journal of Environmental Studies and Management, 2, 12-28.

Brandeis, T. J., Delaney, M., Parresol, B. R., \& Royer, L. (2006). Development of Equations for Predicting Puerto Rican Subtropical Dry Forest Biomass and Volume. Forest Ecology and Management, 233, 133-142. https://doi.org/10.1016/j.foreco.2006.06.012

Brown, S. (2002). Measuring Carbon in Forests: Current Status and Future Challenges. Environmental Pollution, 116, 363-372. https://doi.org/10.1016/S0269-7491(01)00212-3

Brown, S. (2015). Estimating Biomass and Biomass Change of Tropical Forests: A Primer Estimating Biomass and Biomass Change of Tropical Forests: A Primer. FAO Forestry Paper-134. https://www.researchgate.net/publication/239974368

Carreiras, J. M. B., Quegan, S., Le Toan, T., Minh, D. H. T., Saatchi, S. S. et al. (2017). Remote Sensing of Environment Coverage of High Biomass Forests by the ESA BIOMASS Mission under Defense Restrictions. Remote Sensing of Environment, 196, 154-162. https://doi.org/10.1016/j.rse.2017.05.003

Chakravarty, S., Ghosh, S., Suresh, C., Dey, A. N., \& Shukla, G. (2011). Deforestation: Causes, Effects and Control Strategies. CdnIntechopenCom [Internet], 3-29. http://cdn.intechopen.com/pdfs/36125/InTech-Deforestation_causes_effects_and_cont 
rol_strategies.pdf

Chave, J., Andalo, C., Brown, S. et al. (2005). Tree Allometry and Improved Estimation of Carbon Stocks and Balance in Tropical Forests. Oecologia, 145, 87-99. https://doi.org/10.1007/s00442-005-0100-x

Chave, J., Riéra, B., \& Dubois, M.-A. (2013). Estimation of Biomass in a Neotropical Forest of French Guiana: Spatial and Temporal Variability. Journal of Tropical Ecology, 17, 79-96. http://journals.cambridge.org/abstract_S0266467401001055 https://doi.org/10.1017/S0266467401001055

Cole, T. G., \& Ewel, J. J. (2006). Allometric Equations for Four Valuable Tropical Tree Species. Forest Ecology and Management, 229, 351-360. https://doi.org/10.1016/j.foreco.2006.04.017

Couralet, C., Sass-Klaassen, U., Sahle, Y., Sterck, F., Bekele, T., \& Bongers, F. (1992). Dendrochronological Investigations on Juniperus procera from Ethiopian Dry Afromontane Forests. 73-79.

Delitti, W. B. C., Meguro, M., \& Pausas, J. G. (2006). Biomass and Mineralmass Estimates in a "Cerrado" Ecosystem. Revista Brasileira de Botanica, 29, 531-540. https://doi.org/10.1590/S0100-84042006000400003

Djomo, A. N., Ibrahima, A., Saborowski, J., \& Gravenhorst, G. (2010). Forest Ecology and Management Allometric Equations for Biomass Estimations in Cameroon and Pan Moist Tropical Equations Including Biomass Data from Africa. Forest Ecology and Management, 260, 1873-1885. https://doi.org/10.1016/j.foreco.2010.08.034

Dutcă, I. (2018). Biomass Data for Young, Planted Norway Spruce (Picea abies (L.) Karst.) Trees in Eastern Carpathians of Romania. Data in Brief, 19, 2384-2392. https://www.researchgate.net/publication/326514809

Dutcă, I., Abrudan, I. V., Stancioiu, P. T., \& Blujdea, V. (2010). Biomass Conversion and Expansion Factors for Young Norway Spruce (Picea abies (L.) Karst.) Trees Planted on Non-Forest Lands in Eastern Carpathians. Notulae Botanicae Horti Agrobotanici Cluj-Napoca, 38, 286-292.

Ezenwenyi, J. U., Oladoye, A., Chukwu, O., \& Basiru, A. O. (2018). Diameter Distribution of Nauclea diderrichii (D Wild) Merr. Plantations in a Restricted Tropical Rainforest of Nigeria. Journal of Research in Forestry, Wildlife \& Environment, 10, 25-32. https://www.researchgate.net/publication/328730068

Foli, E. G., Alder, D., Miller, H. G., \& Swaine, M. D. (2003). Modelling Growing Space Requirements for Some Tropical Forest Tree Species. Forest Ecology and Management, 173, 79-88. https://doi.org/10.1016/S0378-1127(01)00815-5

Fox, T. R. (2000). Sustained Productivity in Intensively Managed Forest Plantations. Forest Ecology and Management, 138, 187-202. https://doi.org/10.1016/S0378-1127(00)00396-0

Gibbs, H. K., Brown, S., Niles, J. O., \& Foley, J. A. (2007). Monitoring and Estimating Tropical Forest Carbon Stocks: Making REDD a Reality. Environmental Research Letters, 2, Article ID: 045023. http://stacks.iop.org/ERL/2/045023 https://doi.org/10.1088/1748-9326/2/4/045023

Giri, N., Kumar, R., Rawat, L., \& Kumar, P. (2014). Development of Biomass Expansion Factor (BEF) and Estimation of Carbon Pool in Ailanthus excelsa Roxb Plantation. Journal of Chemical Engineering \& Process Technology, 5, Article ID: 1000210.

Gómez-García, E., Crecente-Campo, F., Tobin, B., Hawkins, M., Nieuwenhuis, M., \& Diéguez-Aranda, U. (2014). A Dynamic Volume and Biomass Growth Model System for Even-Aged Downy Birch Stands in South-Western Europe. Forestry, 87, 165-176.

Gregoire, T., \& Köhl, M. (2000). Statistical Ecology and Forest Biometry. Environmental 
and Ecological Statistics, 7, 213-216. https://doi.org/10.1023/A:1009687231250

Günlü, A., Ercanli, I., Başkent, E. Z., \& Çakır, G. (2014). Estimating Aboveground Biomass Using Landsat TM Imagery: A Case Study of Anatolian Crimean Pine Forests in Turkey. Annals of Forest Research, 57, 289-298.

Henry, M., Besnard, A., Asante, W. A., Eshun, J., Adu-Bredu, S., Valentini, R. et al. (2010). Wood Density, Phytomass Variations within and among Trees, and Allometric Equations in a Tropical Rainforest of Africa. Forest Ecology and Management, 260, 1375-1388. https://doi.org/10.1016/j.foreco.2010.07.040

Hjelm, B. (2011). Taper and Volume Equations for Poplar Trees Growing on Farmland in $S$ weden. Licentiate Thesis, Uppsala: Swedish University of Agricultural Sciences.

Hjelm, B. (2015). Empirical Models for Estimating Volume and Biomass of Poplars on Farmland in Sweden. Doctoral Thesis, Uppsala: Swedish University of Agricultural Sciences.

Jalkanen, A., Mäkipää, R., Ståhl, G., Lehtonen, A., \& Petersson, H. (2005). Estimation of the Biomass Stock of Trees in Sweden: Comparison of Biomass Equations and Age-Dependent Biomass Expansion Factors. Annals of Forest Science, 62, 845-851.

Kalita, R. M., Das, A. K., \& Nath, A. J. (2015). Allometric Equations for Estimating Above- and Belowground Biomass in Tea (Camellia sinensis (L.) O. Kuntze) Agroforestry System of Barak Valley, Assam, Northeast India. Biomass and Bioenergy, 83, 42-49. https://doi.org/10.1016/j.biombioe.2015.08.017

Kebede, B., \& Soromessa, T. (2018). Allometric Equations for Aboveground Biomass Estimation of Olea europaea L. subsp. cuspidata in Mana Angetu Forest. Ecosystem Health and Sustainability, 4, 1-12. https://doi.org/10.1080/20964129.2018.1433951

Kozak, A., \& Kozak, R. (2003). Does Cross Validation Provide Additional Information in the Evaluation of Regression Models? Canadian Journal of Forest Research, 33, 976-987. https://doi.org/10.1139/x03-022

Lehtonen, A., Mäkipää, R., Heikkinen, J., Sievänen, R., \& Liski, J. (2004). Biomass Expansion Factors (BEFs) for Scots Pine, Norway Spruce and Birch According to Stand Age for Boreal Forests. Forest Ecology and Management, 188, 211-224. https://doi.org/10.1016/j.foreco.2003.07.008

Li, C.-P., \& Xiao, C.-W. (2007). Above- and Belowground Biomass of Artemisia ordosica Communities in Three Contrasting Habitats of the Mu Us Desert, Northern China. Journal of Arid Environments, 70, 195-207. https://doi.org/10.1016/j.jaridenv.2006.12.017

Lumbres, R. I. C., Lee, Y. J., Seo, Y. O., Kim, S. H., Choi, K., \& Lee, W. K. (2011). Development and Validation of Nonlinear Height-DBH Models for Major Coniferous Tree Species in Korea. Forest Science and Technology, 7, 117-125.

https://doi.org/10.1080/21580103.2011.594610

Mugasha, W. A., Mwakalukwa, E. E., Luoga, E., Malimbwi, R. E., Zahabu, E. et al. (2016). Allometric Models for Estimating Tree Volume and Aboveground Biomass in Lowland Forests of Tanzania. International Journal of Forestry Research, 2016, Article ID: 8076271. https://doi.org/10.1155/2016/8076271

Mulat, A., \& Soromessa, T. (2016). Allometric Equation for Biomass Estimation of Cordia africana Lam. in Tumata Chirecha Agroforestry Gedeo Zone: Implication for Sustainable Management and Climatic Change Mitigation. Journal of Biology, Agriculture and Healthcare, 6, 11-20.

Ounban, W., Puangchit, L., \& Diloksumpun, S. (2016). Development of General Biomass Allometric Equations for Tectona grandis Linn.f. and Eucalyptus camaldulensis 
Dehnh. Plantations in Thailand. Agriculture and Natural Resources, 50, 48-53.

Oyamakin, S. O. (2011). Height-Diameter Relationship in Tree Modeling Using Simultaneous Equation Techniques in Correlated Normal Deviates. Journal of Modern Applied Statistical Methods, 10, 676-685. http://digitalcommons.wayne.edu/jmasm https://doi.org/10.22237/jmasm/1320121500

Pearson, T., Walker, S., \& Brown, S. (2005). Sourcebook for Land Use, Land-Use Change and Forestry Projects.

Ribeiro, S. C., Fehrmann, L., Soares, C. P. B., Jacovine, L. A. G., Kleinn, C., de Oliveira Gaspar, R. (2011). Above- and Belowground Biomass in a Brazilian Cerrado. Forest Ecology and Management, 262, 491-499. https://doi.org/10.1016/j.foreco.2011.04.017

Segura, M., \& Kanninen, M. (2005). Allometric Models for Tree Volume and Total Aboveground Biomass in a Tropical Humid Forest in Costa Rica. Biotropica, 37, 2-8. https://doi.org/10.1111/j.1744-7429.2005.02027.x

Segura, M., Kanninen, M., \& Suárez, D. (2006). Allometric Models for Estimating Aboveground Biomass of Shade Trees and Coffee Bushes Grown Together. Agroforestry Systems, 68, 143-150. https://doi.org/10.1007/s10457-006-9005-x

Siregar, C. A. (2011). Develop Forest Carbon Standard and Carbon Accounting System for Small-Scale Plantation Based on Local Experiences. Project Technical Report, Enhancing Forest Carbon Stock to Reduce Emission from Deforestation and Degradation through Sustainable Forest Management (SFM) Initiatives in Indonesia. 2 (July).

Somogyi, Z., Teobaldelli, M., Federici, S. et al. (2008). Allometric Biomass and Carbon Factors Database. iForest-Biogeosciences and Forestry, 1, 107-113.

https://doi.org/10.3832/ifor0463-0010107

Subasinghe, U. (2008). Growth Models and Their Use in Plantation Forestry. Silver In: Jubilee Proceedings of the Department of Forestry and Environmental Science. https://www.researchgate.net/publication/264239609

Tesfaye, M. A., Bravo-Oviedo, A., Bravo, F., \& Ruiz-Peinado, R. (2016). Aboveground Biomass Equations for Sustainable Production of Fuelwood in a Native Dry Tropical Afro-Montane Forest of Ethiopia. Annals of Forest Science, 73, 411-423. https://doi.org/10.1007/s13595-015-0533-2

Troxel, B., Piana, M., Ashton, M. S., \& Murphy-Dunning, C. (2013). Urban Forestry \& Urban Greening Relationships between Bole and Crown Size for Young Urban Trees in the Northeastern USA. Urban Forestry \& Urban Greening, 12, 144-153. https://doi.org/10.1016/j.ufug.2013.02.006

Van Breugel, M., Ransijn, J., Craven, D., Bongers, F., \& Hall, J. S. (2011). Forest Ecology and Management Estimating Carbon Stock in Secondary Forests: Decisions and Uncertainties Associated with Allometric Biomass Models. Forest Ecology and Management, 262, 1648-1657. https://doi.org/10.1016/j.foreco.2011.07.018

Vieira, S. A., Alves, L. F., Aidar, M., Araújo, L. S. et al. (2008). Estimation of Biomass and Carbon Stocks: The Case of the Atlantic Forest. Biota Neotropica, 8, 21-29. http://www.biotaneotropica.org.br/v8n2/en/abstract?point-of-view+bn00108022008 https://doi.org/10.1590/S1676-06032008000200001

Viken, K. O. (2012). Biomass Equations and Biomass Expansion Factors (BEFs) for Pine (Pinus spp.), Spruce (Picea spp.) and Broadleaved Dominated Stands in Norway. Master's Thesis, Ås, Norway: Norwegian University of Life Sciences.

Worku, E., \& Soromessa, T. (2015). Allometric Equation for Biomass Determination in Juniperus procera Endl. and Podocarpus falcatus Mirb of Wof-Washa Forest: Implication for Climate Change Mitigation. American Journal of Life Sciences, 3, 190-202. http://www.sciencepublishinggroup.com/j/ajls 
https://doi.org/10.11648/j.ajls.20150303.20

Yitebitu, M., Zewdu, E., \& Sisay, N. (2010). Ethiopian Forest Resources: Current Status and Future Management Options in View of Access to Carbon Finances. Ethiopian Climate Research and Networking and United Nations Development Programme.

Yohannes, Y. (2002). Aboveground Biomass and Stem Volume Functions of Eucalyptus globulus Labill Coppice Trees Grown in Addis Ababa. Master Thesis, Umeå: Swedish University of Agricultural Sciences.

Zhao, D., Kane, M., Teskey, R., \& Markewitz, D. (2016). Modeling Aboveground Biomass Components and Volume-to-Weight Conversion Ratios for Loblolly Pine Trees. Forest Science, 62, 463-473. https://doi.org/10.5849/forsci.15-129

Zianis, D., \& Mencuccini, M. (2004). On Simplifying Allometric Analyses of Forest Biomass. Forest Ecology and Management, 187, 311-332.

https://doi.org/10.1016/j.foreco.2003.07.007

Zianis, D., Muukkonen, P., Mäkipää, R., \& Mencuccini, M. (2005). Biomass and Stem Volume Equations for Tree Species in Europe. Silva Fennica Monographs, 4, 63 p. https://www.researchgate.net/publication/232304857 